\title{
Environmental impact assessment of three packages for high-quality extra-virgin olive oil
}

\author{
Antonio Guiso, Alessandro Parenti, Piernicola Masella, Lorenzo Guerrini, Fabio Baldi, \\ Paolo Spugnoli
}

Department of Agricultural, Food and Forestry Systems, University of Firenze, Italy

\begin{abstract}
Life cycle assessments of food packaging technologies have shown that they contribute considerably to the environmental impact of products. This study analyses the life cycle impact of three packaging solutions for high-quality extra-virgin olive oil. Two of them are widely used solutions, namely tin plated cans and dimmed glass bottles. The third one is a stainless steel bottle, which has been proposed recently. The analysis was performed with a cradle to grave approach and it takes into account raw materials extraction and processing, packaging production processes and several end-of-life scenarios. Impacts due to distribution were considered separately to assess uncertainties due to distribution distances. The results show that, for same sizes, dimmed glass bottles have the lowest overall impact value for all the six indicators selected except for ozone layer depletion, whereas stainless steel bottles have the highest impact values for all the other indicators. A sensitivity analysis was performed to determine how impact varies in function of distance and packaging weight. It shows that it is possible to set a breakeven point over which the impact of glass overcomes the one of the other packaging systems. Packaging shows a significant contribution to impact of bottled oil. For small packaging, such as a $0.100 \mathrm{~L}$ stainless steel bottle, this contribution can be as relevant as $60 \%$ of the overall global warming potential.
\end{abstract}

Correspondence: Antonio Guiso, Department of Agricultural, Food and Forestry Systems (GESAAF), University of Firenze, piazzale delle Cascine 18, 50144 Firenze, Italy.

Tel.: +39.0553.288352.

E-mail: antonio.guiso@unifi.it

Key words: Life cycle assessments; global warming potential; shelf life; greenhouse gas.

See online Appendix for supplementary materials.

Received for publication: 4 November 2015.

Accepted for publication: 7 September 2016.

(C) Copyright A. Guiso et al., 2016

Licensee PAGEPress, Italy

Journal of Agricultural Engineering 2016; XLVII:515

doi:10.4081/jae.2016.515

This article is distributed under the terms of the Creative Commons Attribution Noncommercial License (by-nc 4.0) which permits any noncommercial use, distribution, and reproduction in any medium, provided the original author(s) and source are credited.

\section{Introduction}

Extra-virgin olive oil is an edible fat, which has a relevant nutritional value and sensorial characteristics. Its quality is defined by the high content of oleic acid, and other minor compounds such as tocopherols and biophenols. Oil quality decreases during storage due to oxidation phenomenon, which leads to the depletion of its sensorial and nutritional properties (Fortini et al., 2016). The oxidation rate depends on oxygen availability, amount of light and temperature (Pristouri, 2010). Hence, packaging directly affects olive oil quality by preventing contact between the atmospheric oxygen and the olive oil, and by protecting it from the light (Kanavouras et al., 2004; Masella et al., 2012) and from temperature variations. Many studies have assessed the effect of packaging technologies on the quality of extra-virgin olive oil (Koidis and Boskou, 2014; Limbo et al., 2014; Gargouri et al., 2015). These works study the oxidation phenomenon due to the contact between oxygen and extra-virgin olive oil and to the effect of the light. They focus on the depletion of the olive oil antioxidant fraction, and on the formation of off-flavour. On the other hand, few works discuss and compare packaging systems in terms of environmental performances (Accorsi et al., 2015). This study compares the environmental footprint of three packages using a life cycle assessment methodology (LCA). LCA is an environmental tool used to assess the environmental performance of products (ISO 14040:2006; ISO, 2006a). Packaging is one of the most intensively studied areas within the field of LCA and it plays an especially important role in the case of food consumption (Hischier et al., 2010; Pagani et al., 2015; De Menna et al., 2015). The first example of a comprehensive life cycle environmental assessment of a product was conceived in the late 1960 s by Harry E. Teasley Jr. for the entire life cycle of a package from the extraction of raw materials to its disposal (Hunt et al., 1996). The aim was to provide the company with an instrument to support its packaging policy decision and select among different packaging options with comparable features.

Packaging has a relevant contribution to the final product environmental impact, since its life cycle might be longer than the product itself and it represents the main stream of waste in the end of product life scenario. Often packaging has a higher impact than the product it contains. Its preserving function is particularly important in the market segment of high-quality food products (Kiritsakis and Dugan, 1984). Two widely used solutions for packaging high-quality extra-virgin olive oil are tin plated cans and glass bottles packed in dark boxes (Limbo et al., 2015). Furthermore, a new stainless steel bottle has been recently proposed by Olipac. These three packaging systems fulfil their main function of preserving oil quality. Therefore, the selection among these systems may depend on other factors such as production costs, aesthetic marketing aspects and environmental performances. Among these, sustainability has recently become a key driver for companies and consumer preference (Luchs et al., 2010). 


\section{Materials and methods}

\section{Goal and scope of the study}

The main goal of this study is to provide a comparative life cycle impact assessment of three extra-virgin olive oil packaging solutions: tin plated cans, dimmed glass bottles and stainless steel bottles. The analysis has been carried out using $0.250 \mathrm{~L}$ and $0.500 \mathrm{~L}$ containers since they are the most commonly used and there is limited availability of stainless steel bottles of different sizes. We also assess the contribution of the package to the impact indicators of the final product (bottled oil), as well as the impact due to distribution to final consumers of all three packaging solutions.

The methodological framework adopted is defined in the standards IS0:14040 and ISO:14044 (ISO, 2006a, 2006b), which provide a systematic approach and regulation on LCA of products. Therefore, a cradle-tograve approach has been adopted, from raw material extraction, through formation process to the end of life disposal of residual products (Madival et al., 2009). Impact assessment of the three packaging systems has been carried out using the 2013 Environmental Product Declaration (EPD®) impact assessment method also available on Simapro and widely used for product life cycle impact assessment (EPD® System, 2008). This method considers six impact measurement indicators: global warming potential (IPCC, 2013), ozone layer depletion (WM0, 2006), photochemical oxidation (Jenkin and Hayman, 1999), acidification (Hauschild and Wenzel, 1998), eutrophication (Heijungs et al., 1992), and non-renewable energy (World Resources, 1992). The respective reference units are $\mathrm{kg} \mathrm{CO}_{2}$ eq., g $\mathrm{CFC}-11$ eq., g $\mathrm{C}_{2} \mathrm{H}_{4}$ eq., g SO $\mathrm{S}_{2}$ eq., g $\mathrm{PO}_{4}$ eq., and $\mathrm{MJ}$ eq.

\section{Functional unit}

The functional unit (FU) chosen is $1 l$ of bottling capacity. The EPD® of Olio Monini (EPD® System, 2012) has been used as reference for the evaluation of environmental impact of unpacked extra-virgin olive oil, with the purpose of assessing the contribution of packaging technologies to the overall product impact.

\section{System boundaries}

Figure 1 shows the system boundaries used to define the flows from and to the systems. Following, a description of the production processes of the three technologies.

Tin plated cans and stainless steel bottles are made of steel, which is an alloy of iron and carbon. Iron is extracted from iron ore and then processed to obtain different quality of steel (Russel et al., 2013). Stainless steel bottles are made of chromium steel 18/10, which is an alloy of iron with a low carbon content (usually less than $0.1 \%$ ), chromium (18\%) and nickel (10\%). Primary ingots are then hot rolled into sheets. Bottle components are obtained through an impact extrusion process and then arch welded to form the bottle. Cans are made from sheets of tin plated steel. Sheets are obtained by rolling primary steel to a thickness of $0.2 \mathrm{~mm}$, which are then subjected to an electroplating process to create a tin coat layer which avoids steel oxidation (Thomson, 1994). The pieces necessary to produce the can are impact extruded from the sheets and then joined together through a welding process.

Green glass bottles are made by melting in furnaces both a primary glass batch and recycled glass scrap on a variable percentage (between 80 and $85 \%$ of recycled glass according to Ecoinvent Report (Hischer, 2007). The primary glass batch is a mix of sand, soda, limestone dolomite and feldspar, whose extraction and processing is also considered in this study (De Jong, 1989). The bottle is manufactured with a blow and blow process. Bottles are corked with aluminium caps and a polyethylene drip-catcher. Once full, bottles are sealed in cardboard boxes to preserve the oil from light oxidation. Boxes are made of Kraft paper, consisting of a layer of corrugated sheet enclosed in two layers of flat liner-board. Similarly, stainless steel bottles and tin plated cans are provided with polyethylene drip catcher and cap, which are produced by thermoforming of polyethylene, granulate.

The study considers several end of life scenarios, one for each of the materials used in the product assembly. Each scenario is implemented as a percentage of three disposal methodologies: landfill, incineration

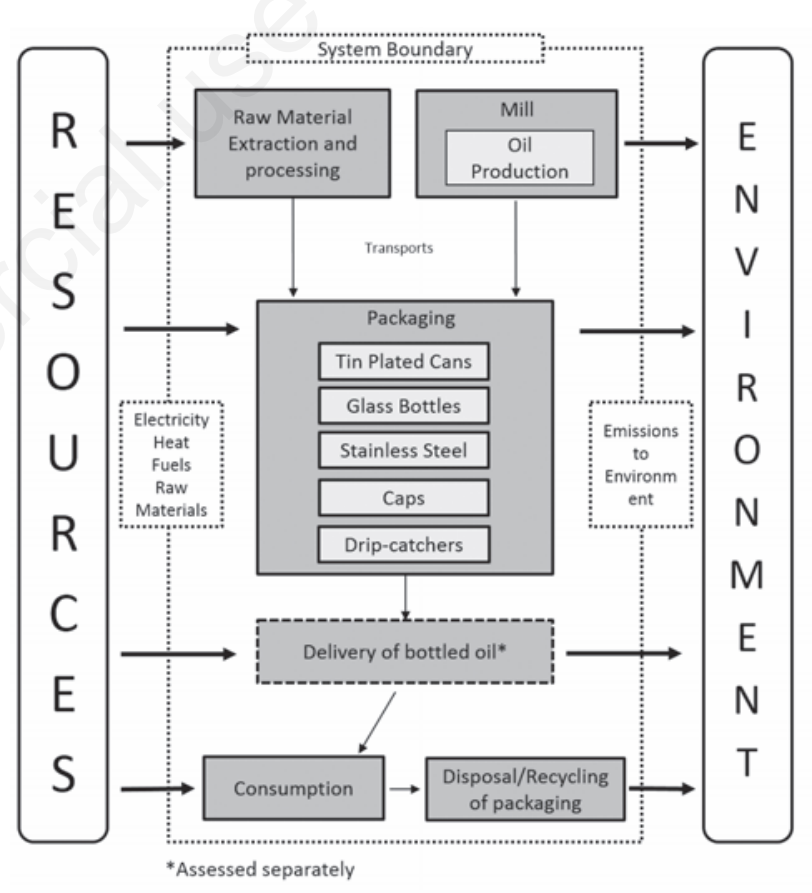

Figure 1. System boundary.

Table 1. Packaging sizes and weights.

\begin{tabular}{|c|c|c|c|c|c|c|}
\hline Tin plated cans & $\begin{array}{l}\text { Size (l) } \\
\text { Mean weight (g) } \\
\text { SD }\end{array}$ & $\begin{array}{l}0.25 \\
0.067 \\
0.008\end{array}$ & $\begin{array}{c}0.5 \\
0.088 \\
0.010\end{array}$ & $\begin{array}{c}1 \\
0.121 \\
0.010\end{array}$ & $\begin{array}{c}3 \\
0.346 \\
0.033\end{array}$ & $\begin{array}{c}5 \\
0.446 \\
0.036\end{array}$ \\
\hline Glass & $\begin{array}{l}\text { Size (l) } \\
\text { Mean weight (g) } \\
\text { SD }\end{array}$ & $\begin{array}{l}0.250 \\
0.256 \\
0.026\end{array}$ & $\begin{array}{l}0.500 \\
0.377 \\
0.035\end{array}$ & $\begin{array}{l}0.750 \\
0.484 \\
0.033\end{array}$ & $\begin{array}{l}1.000 \\
0.595 \\
0.049\end{array}$ & $\begin{array}{l}- \\
- \\
-\end{array}$ \\
\hline INOX & $\begin{array}{l}\text { Size (l) } \\
\text { Mean weight (g) }\end{array}$ & $\begin{array}{l}0.100 \\
0.040\end{array}$ & $\begin{array}{l}0.250 \\
0.073\end{array}$ & $\begin{array}{l}0.500 \\
0.101\end{array}$ & - & $\begin{array}{l}- \\
-\end{array}$ \\
\hline
\end{tabular}

SD, standard deviation. 
and recycling. According with IS0:14044, paragraph 4.3.4.3.1, recycling has been considered as a process that is outside the system boundaries, therefore its impact is considered equal to zero. Data on material disposal percentages come from the reports of Italian consortiums for recovery and recycling (Mazzanti and Zoboli, 2008; COMIECO, 2013; PlasticsEurope, 2013; CoReVe, 2014).

Regarding the impact derived from transport, the study considers data related to the transport of raw materials and unfinished products between productions sites, but it does not include the impact due to distribution to final consumers, since the distance that the product covers is highly variable. It depends on the location of production and their market segment; therefore, it is not possible to define a univocal value. However, a sensitivity analysis has been performed to assess how impact of bottled oil varies in function of distance and packaging weight. This study does not consider secondary packaging and labelling.

\section{Life cycle inventories}

The life cycle inventories (LCI) collect the flows of materials, energy and waste of the packaging systems analysed. Primary data regarding material weights, used to define foreground processes in LCI, are based on 48 packaging samples. Data regarding materials and production processes were gathered from product technical sheets and literature review. Glass bottle and tin plated can samples were purchased in five furniture shops in the Florentine area, while stainless steel bottles were directly provided by the producer firm Olipac, brand of IPAC S.p.A, based in Serravalle (PT) - Italy. Several sizes, representative of the most commonly used on the Italian market have been included for each packaging system (Table 1). Additionally, five samples of each size of glass and tin plated containers were analysed to discern the production differences between the various packaging brands. Mean values are used to define the LCI primary data of each system. Only one sample for each stainless steel bottle size has been measured, since only one bottle brand is available on the Italian market. The analysis includes also the caps, which are provided with the bottles. They represent the standard for olive oil packaging: PET drip-catcher and aluminium cap for glass bottles, PET cap for tin plated cans and stainless steel bottles.

Secondary data, regarding emission factors of production processes, raw material extraction, and processing were obtained from the EconIvent database version 3 of the Swiss Centre for Life Cycle. Details regarding the LCIs have been provided as supplementary materials (Appendix). The LCI has been analysed with the software Simapro (8.0.2, pre-sustainability-2014, UK).

The analysis preformed in this study includes some uncertainties, which are related to sampling of packaging technologies and the use of secondary data (e.g., EcoInvent Database). The influence of these uncertainties on the results has been assessed with a MonteCarlo analysis (confidence interval 95\%).

\section{Results and discussion}

The results obtained are initially presented separately for each packaging system, with a comparison of the three systems following. The functional unit, to which all the results have been reported, is $1 \mathrm{~L}$ of bottling capacity.

The result of the environmental impact assessment of stainless steel bottles are presented in Table 2 . The relation between size and impact is not linear, indeed the global warming potential (GWP) indicator varies from $3.404 \mathrm{~kg} \mathrm{CO}_{2}$ eq. for the $0.1 l$ bottle to the $1.6084 \mathrm{~kg} \mathrm{CO}_{2}$ eq. of the $0.5 l$ per FU. An analysis of the impact of single life cycle stages shows that the production process of the bottle, including raw material extraction and processing, has the highest impact for all the indicators. Production of cap and drip-catcher is the second contributor for all the indicators but Eutrophication potential, for which end of life stage represents the second contributor to the overall impacts (Figure 2). The high impact of the production process is mainly due to the manufacturing of primary stainless steel ingots.

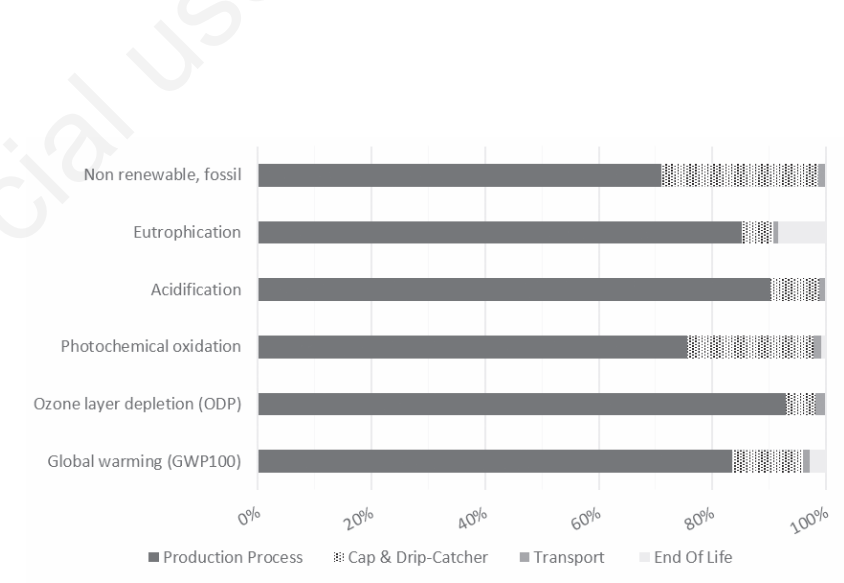

Figure 2. Contribution of life cycle stages to the overall impact of a $0.250 l$ stainless steel bottle.

Table 2. Impact indicators of analysed packaging systems (functional unit $1 \mathrm{~L}$ ).

\begin{tabular}{|c|c|c|c|c|c|c|c|}
\hline & $\begin{array}{l}\text { Impact } \\
\text { category } \\
\text { unit }\end{array}$ & $\begin{array}{c}\text { Global } \\
\text { warming } \\
\mathrm{kg} \mathrm{CO} \text { eq }\end{array}$ & $\begin{array}{l}\text { Ozone layer } \\
\text { depletion } \\
\text { mg CFC-11 eq }\end{array}$ & $\begin{array}{c}\text { Photochemical } \\
\text { oxidation } \\
\text { g } \mathrm{C}_{2} \mathrm{H} 4 \mathrm{eq}\end{array}$ & $\begin{array}{l}\text { Acidification } \\
\qquad \mathrm{g} \mathrm{SO}_{2} \mathrm{eq}\end{array}$ & $\begin{array}{l}\text { Eutrophication } \\
\qquad \text { g } \mathrm{PO}_{4} \mathrm{eq}\end{array}$ & $\begin{array}{c}\text { No renew. } \\
\text { energy } \\
\text { MJ eq }\end{array}$ \\
\hline Stainless & $\begin{array}{l}0.100 l \\
0.250 l \\
0.500 l\end{array}$ & $\begin{array}{l}3.404 \\
2.276 \\
1.608\end{array}$ & $\begin{array}{l}0.132 \\
0.092 \\
0.066\end{array}$ & $\begin{array}{l}3.848 \\
2.448 \\
1.691\end{array}$ & $\begin{array}{c}17.001 \\
11.687 \\
8.357\end{array}$ & $\begin{array}{l}5.900 \\
4.006 \\
2.850\end{array}$ & $\begin{array}{l}50.272 \\
31.448 \\
21.556\end{array}$ \\
\hline Tin plated & $\begin{array}{c}0.250 l \\
0.500 l \\
1 l \\
3 l \\
5 l\end{array}$ & $\begin{array}{l}1.589 \\
1.056 \\
0.867 \\
0.554 \\
0.438\end{array}$ & $\begin{array}{l}0.142 \\
0.096 \\
0.080 \\
0.051 \\
0.041\end{array}$ & $\begin{array}{l}2.194 \\
1.451 \\
1.184 \\
0.756 \\
0.597\end{array}$ & $\begin{array}{l}8.745 \\
5.849 \\
4.838 \\
3.096 \\
2.455\end{array}$ & $\begin{array}{l}2.513 \\
1.676 \\
1.381 \\
0.883 \\
0.700\end{array}$ & $\begin{array}{c}19.969 \\
13.011 \\
10.426 \\
6.637 \\
5.206\end{array}$ \\
\hline Glass & $\begin{array}{c}0.250 l \\
0.500 l \\
0.750 l \\
1 l\end{array}$ & $\begin{array}{l}1.302 \\
0.969 \\
0.818 \\
0.740\end{array}$ & $\begin{array}{l}0.102 \\
0.077 \\
0.064 \\
0.060\end{array}$ & $\begin{array}{l}1.148 \\
0.837 \\
0.692 \\
0.630\end{array}$ & $\begin{array}{l}7.617 \\
5.726 \\
4.761 \\
4.426 \\
\end{array}$ & $\begin{array}{l}2.176 \\
1.625 \\
1.429 \\
1.236 \\
\end{array}$ & $\begin{array}{l}19.752 \\
14.505 \\
11.952 \\
10.980 \\
\end{array}$ \\
\hline
\end{tabular}


Tin plated cans are among the most common and versatile packaging systems for high-quality olive oil and are commercially available in a wide number of sizes, generally from $0.250 l$ up to $5 l$. Impact indicators for tin plated cans are presented in Table 2. The GWP varies from $1.5888 \mathrm{~kg} \mathrm{CO}_{2}$ eq. for the $0.250 l$ down to $0.43808 \mathrm{~kg} \mathrm{CO}_{2}$ eq. for the $5 l$ can. In line with stainless steel bottles, the production process represents the highest contributor to all impact indicators for tin plated cans (Figure 3). The impact of the production process is mainly due to the electrolytic tin plating process.

As previously underlined, glass bottles need to be dimmed with a cardboard box. Cardboard boxes production represents and additional life cycle stage, which has a relevant impact (from 11\% of GWP up to $18 \%$ of eutrophication potential). Compared with the other two packaging systems, primary raw material production and processing has a lower contribution to the overall impact, mainly because the high rate of recycled material used in the production process. For $0.250 \mathrm{~L}$ bottle, glass production impact varies from $44 \%$ of eutrophication potential up to $69 \%$ of not renewable energy use (Figure 4). Cardboard box production is the second contributor, except for eutrophication potential, whose end of life scenario is responsible for the $27 \%$ of the total. Impact indicators for glass bottles are presented in Table 2.

The comparison of the impact indicators of the three packaging systems has been carried out for $0.250 l$ and $0.500 l$ size. Results are synthesized in Table 3. Stainless steel bottles have the highest impact for all the indicators, except for the ozone layer depletion, which is higher for thin plated cans, mainly because of electrolytic tin plating process.
Glass bottles appear to have the lowest environmental impact for all the indicators considered.

Packaging has a relevant contribution on finished product environmental impact. This contribution has been assessed considering a functional unit of $1 l$ of bottled oil (Table 4). A $0.100 l$ tin plated can, which has the highest environmental impact among the packaging systems considered, is responsible for the $20.6 \%$ of oil eutrophication potential, as much as the $60.2 \%$ of the GWP of bottled oil. Packaging impact decreases for larger sizes, for instance, contribution of tin plated cans to oil GWP decreases from $41 \%$ for a $0.250 l$ can, to $16 \%$ for $5 l$ can. However, it is not common to find sizes larger than $1 \mathrm{~L}$ for highquality extra-virgin olive oil.

Results presented in this study appear to be in line with literature, which shows that the high contribution of packaging to product environmental footprint is common in the whole food and beverage sector (Andersson, 2000; Krozer, 2008; Roy et al., 2008). For instance, packaging is responsible of around one-third of the total environmental impact of beer production (Hospido et al., 2005).

In the olive oil industry, selection of packaging technology and materials represents a key factor in terms of product environmental impact because of low production yields and extraction rate (Pattara et al., 2016).

Packaging environmental impact still represents a marginal factor to influence producer preference regarding packaging technology, despite the high contribution to the environmental footprint of final products. The main key factors in packaging selections are aesthetic handling

Table 3. Comparison between packaging technologies (functional unit $1 \mathrm{~L}$ ).

\begin{tabular}{|c|c|c|c|c|c|}
\hline Impact category & Unit & Sizes & Can & Stainless & Glass \\
\hline Global warming & $\mathrm{kg} \mathrm{CO}$ eq & $\begin{array}{l}0.250 l \\
0.500 l\end{array}$ & $\begin{array}{l}1.5886 \\
1.0558\end{array}$ & $\begin{array}{l}2.2759 \\
1.6083\end{array}$ & $\begin{array}{l}1.3021 \\
0.9689\end{array}$ \\
\hline Ozone layer depletion & mg CFC-11 eq & $\begin{array}{l}0.250 l \\
0.500 l\end{array}$ & $\begin{array}{l}0.1419 \\
0.0955\end{array}$ & $\begin{array}{l}0.0916 \\
0.0657\end{array}$ & $\begin{array}{l}0.1016 \\
0.0772\end{array}$ \\
\hline Photochemical oxidation & $\mathrm{g} \mathrm{C}_{2} \mathrm{H}_{4} \mathrm{eq}$ & $\begin{array}{l}0.250 l \\
0.500 l\end{array}$ & $\begin{array}{l}2.1936 \\
1.4510\end{array}$ & $\begin{array}{l}2.4477 \\
1.6910\end{array}$ & $\begin{array}{l}1.1484 \\
0.8370\end{array}$ \\
\hline Acidification & $\mathrm{g} \mathrm{SO}_{2} \mathrm{eq}$ & $\begin{array}{l}0.250 l \\
0.500 l\end{array}$ & $\begin{array}{l}8.7447 \\
5.8493\end{array}$ & $\begin{array}{c}11.6870 \\
8.3572\end{array}$ & $\begin{array}{l}7.6168 \\
5.7259\end{array}$ \\
\hline Eutrophication & $\mathrm{g} \mathrm{PO}_{4} \mathrm{eq}$ & $\begin{array}{l}0.250 l \\
0.500 l\end{array}$ & $\begin{array}{l}2.5125 \\
1.6756\end{array}$ & $\begin{array}{l}4.0063 \\
2.8497\end{array}$ & $\begin{array}{l}2.1760 \\
1.6247\end{array}$ \\
\hline Non renewable, fossil & MJ eq & $\begin{array}{l}0.250 l \\
0.500 l\end{array}$ & $\begin{array}{l}19.9689 \\
13.0108\end{array}$ & $\begin{array}{l}31.4476 \\
21.5559\end{array}$ & $\begin{array}{l}19.7523 \\
14.5047\end{array}$ \\
\hline
\end{tabular}

Table 4. Packaging contribution to bottled oil impacts (functional unit $1 \mathrm{~L}$ ).

\begin{tabular}{|c|c|c|c|c|c|c|c|}
\hline & $\begin{array}{l}\text { Impact } \\
\text { category }\end{array}$ & $\begin{array}{l}\text { Global } \\
\text { warming }\end{array}$ & $\begin{array}{l}\text { Ozone layer } \\
\text { depletion }\end{array}$ & $\begin{array}{c}\text { Photochemical } \\
\text { oxidation }\end{array}$ & Acidification & Eutrophication & $\begin{array}{c}\text { No renew. } \\
\text { energy }\end{array}$ \\
\hline Stainless & $\begin{array}{l}0.100 l \\
0.250 l \\
0.500 l\end{array}$ & $\begin{array}{l}36.7 \% \\
30.1 \% \\
26.7 \%\end{array}$ & $\begin{array}{l}16.6 \% \\
13.1 \% \\
11.2 \%\end{array}$ & $\begin{array}{l}30.8 \% \\
24.5 \% \\
21.1 \%\end{array}$ & $\begin{array}{l}35.3 \% \\
29.1 \% \\
25.4 \%\end{array}$ & $\begin{array}{c}14.0 \% \\
10.8 \% \\
9.6 \%\end{array}$ & $\begin{array}{l}31.5 \% \\
25.3 \% \\
21.8 \%\end{array}$ \\
\hline Tin plated & $\begin{array}{c}0.250 l \\
0.500 l \\
1 l \\
3 l \\
5 l\end{array}$ & $\begin{array}{l}41.4 \% \\
32.0 \% \\
27.8 \% \\
19.8 \% \\
16.3 \%\end{array}$ & $\begin{array}{c}21.8 \% \\
15.8 \% \\
13.5 \% \\
9.1 \% \\
7.4 \%\end{array}$ & $\begin{array}{l}45.9 \% \\
36.0 \% \\
31.4 \% \\
22.7 \% \\
18.8 \%\end{array}$ & $\begin{array}{l}38.5 \% \\
29.5 \% \\
25.7 \% \\
18.1 \% \\
14.9 \%\end{array}$ & $\begin{array}{c}15.8 \% \\
11.1 \% \\
9.3 \% \\
6.2 \% \\
5.0 \%\end{array}$ & $\begin{array}{l}31.7 \% \\
23.3 \% \\
19.5 \% \\
13.4 \% \\
10.8 \%\end{array}$ \\
\hline Glass & $\begin{array}{c}0.250 l \\
0.500 l \\
0.750 l \\
1 l\end{array}$ & $\begin{array}{l}60.2 \% \\
50.3 \% \\
41.7 \% \\
60.2 \% \\
\end{array}$ & $\begin{array}{l}20.6 \% \\
15.2 \% \\
11.4 \% \\
20.6 \% \\
\end{array}$ & $\begin{array}{l}59.8 \% \\
48.7 \% \\
39.6 \% \\
59.8 \% \\
\end{array}$ & $\begin{array}{l}54.9 \% \\
45.5 \% \\
37.4 \% \\
54.9 \% \\
\end{array}$ & $\begin{array}{l}30.6 \% \\
23.0 \% \\
17.5 \% \\
30.6 \%\end{array}$ & $\begin{array}{l}53.9 \% \\
42.3 \% \\
33.4 \% \\
53.9 \% \\
\end{array}$ \\
\hline
\end{tabular}


and product protection during its shelf life (Prendergast and Pitt, 1996; Chiellini, 2008). However, packaging policies and the increasing demand of green products from consumers (Rokka and Uusitalo, 2008) are pushing towards a reduction of packaging environmental impact, particularly in Europe, e.g., the EU directive 2004/12/EC (European Commission, 2004).

As previously underlined, this study does not consider the impact caused by the distribution phase of the finished product. This is because it is difficult to estimate the value of distances that the final product has to cover before reaching customers. However, it is possible to estimate the variability of the environmental impact of packaging depending on distance and on the weight of the product. The result shows that it is possible to estimate a breakeven point, expressed in kilometres, for which the impact of glass bottles becomes higher than the one of the other packaging systems. This is because even if production of glass packaging has a lower environmental impact, the final product weighs more. For instance, a $0.250 \mathrm{l}$ of oil bottled in glass weights 461 against $300 \mathrm{~g}$ for oil bottled in tin plated cans. Considering the impact of transport (in kg per km, Ecoinvent Database), the GWP of a $0.250 \mathrm{l}$ glass bottle is higher than a corresponding size can for distances, which exceed $848 \mathrm{~km}$. The acidification potential indicator of glass is higher just after $206 \mathrm{~km}$.

The uncertainty analysis shows that the coefficient of variation span from $3.7 \%$ for ozone layer depletion of $5 \mathrm{~L}$ tin plated can to 31.5 for eutrophication potential of $0.100 \mathrm{~L}$ stainless steel container.

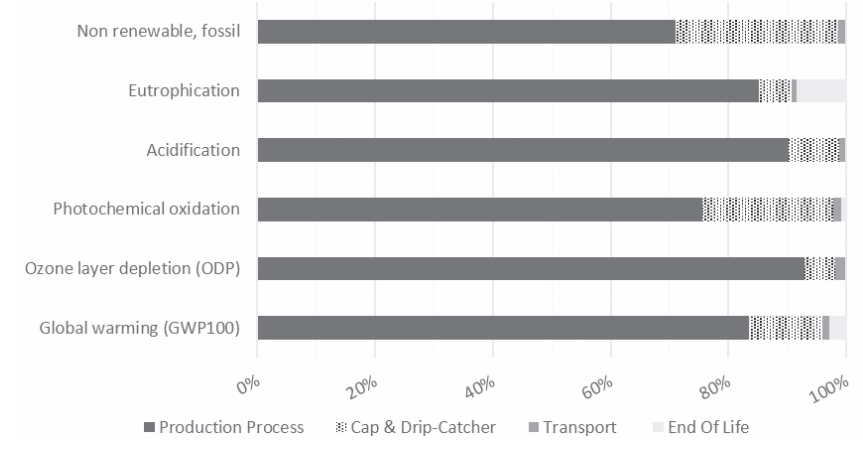

Figure 3. Contribution of life cycle stages to the overall impact of a $0.250 l$ tin plated can.

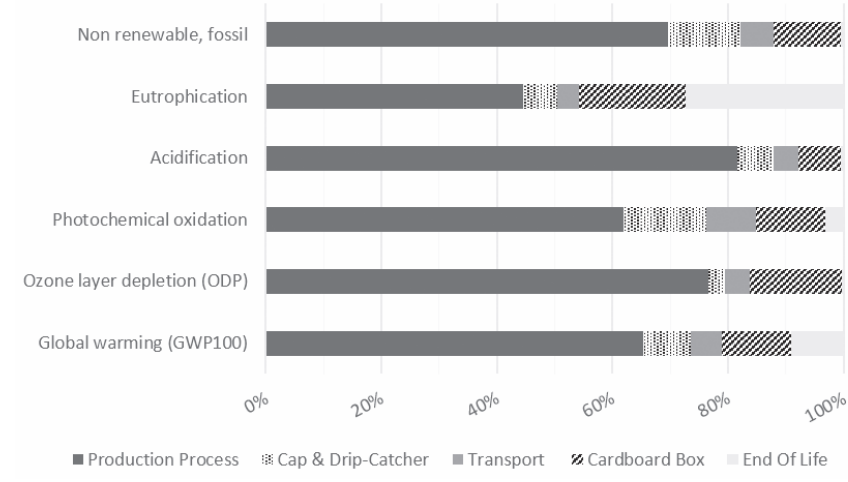

Figure 4. Dimmed glass bottle contribution of life cycle stages to the overall impact of a $0.250 \mathrm{l}$.
Uncertainties vary inversely to packaging size, indeed the CV of impact indicators increase when size decreases.

Influence of the reuse of packaging via reintroduction of container in the oil production chain is assumed limited. Containers are usually provided with no re-filling devices embedded in the drip catcher. Moreover, producers/sellers do not usually provide retirement services. However, further research is necessary to assess the effect of reuse in the consumer size, since containers may be employed to store products other than the original oil after use, although an estimation of the rate of reuse may be extremely difficult. In this case, effect of reuse may be relevant, since environmental impact would be reallocated to the number of reuses and therefore packaging contribution to bottled oil would reduce accordingly. In this case, no changes are expected in the comparison between packaging technologies.

\section{Conclusions}

This study evaluates the environmental impact of three packaging systems used for high-quality extra-virgin olive oil. Among these, stainless steel bottles have the highest environmental impact for all the impact categories, except for the ozone layer depletion. This can be attributed to the production of stainless steel. However, steel bottle is a recent and not widespread packaging on the market. Indeed, dimmed glass bottles and tin plated cans are the most diffuse packaging systems for extra-virgin olive oil. The dimmed glass bottles are the solution with the lowest environmental impact, except for the ozone layer depletion. However, this solution is also the heaviest one; therefore, its impact can change in function of distribution distance. Environmental impact should be taken into account during packaging design phases, since its contribution to product impact can be as relevant as up to $60 \%$ of the global warming potential. This is particularly evident for small size products, which are widespread in the market of high-quality olive oil. In conclusion, the analyses performed show that the most environmentally friendly solutions for olive oil packaging are glass bottles in case of local distribution and tin plated cans in case of long distance distribution.

\section{References}

Accorsi R., Versari L., Manzini R. 2015. Glass vs. plastic: life cycle assessment of extra-virgin olive oil bottles across global supply chains. Sustain. 7:2818-40.

Andersson K. 2000. LCA of food products and production systems. Int. J. Life Cycle Assess. 5:239-48.

Chiellini E. 2008. Environmentally compatible food packaging. Elsevier, Amsterdam, The Netherlands.

COMIECO (Consorzio Nazionale Recupero e Riciclo degli Imballaggio a base Cellulosica). 2013. Rapporto annuale Comieco sulla raccolta differenziata di carta e cartone in Italia. Available from: http://comieco.media.mweb.pro/allegati/2014/7/xix-rapportocomieco_anno-2013_138344.pdf

CoReVe (Consorzio Recupero Vetro). 2014. Risultati di raccolta e riciclo 2013. Available from: https://www.coreve.it/showPage.php?template=homepage

De Jong BHWS. 1989. Glass. Ullmann's encyclopedia of industrial chemistry, 5th ed., vol. A12. VCH Publishers, Weinheim, Germany, pp. $365-432$.

De Menna F., Vittuari M., Molari G. 2015. Impact evaluation of integrated food-bioenergy systems: A comparative LCA of peach nectar. 
Biomass Bioener. 73:48-61.

EPD® System. 2008. General programme instructions for the international EPD® system. Available from: http://www.environdec. com/en/The-International-EPD-System/General-ProgrammeInstructions/Characterisation-factors-for-default-impact-assessment-categories

EPD® System. 2012. Environmental Product Declaration (EPD®) for "GranFruttato" extra virgin olive oil. Monini S.p.A. Rev. 0.0 December 2012; Reg. number S-P-00383. Available from: http:/www.monini.com/sites/default/files/image/Festa/News/EPD\% 20Monini\%20Granfruttato\%20inglese.pdf

European Commission. 2004. Directive 2004/12/EC of the European Parliament and of the Council of 11 February 2004 amending Directive 94/62/EC on packaging and packaging waste - Statement by the Council, the Commission and the European Parliament. In: Official Journal, L 47, 18/02/2004, pp 26-32.

Fortini M., Migliorini M., Cherubini C., Cecchi L., Guerrini L., Masella P., Parenti A. 2016. Shelf life and quality of olive oil filtered without vertical centrifugation. Eur. J. Lipid Sci. Technol. 118:1213-22.

Gargouri B., Zribi A., Bouaziz M. 2015. Effect of containers on the quality of Chemlali olive oil during storage. J. Food Sci Technol. 52:1948-59.

Hauschild M., Wenzel H. 1998. Environmental assessment of products. Scientific background, vol. 2, 1st ed. Chapman \& Hall, London, UK.

Heijungs R., Guinée J.B., Huppes G., Lankreijer R.M., Udo de Haes H.A., Wegener Sleeswijk A., De Goede H.P. 1992. Environmental life cycle assessment of products: guide and backgrounds (part 1). Centre of Environmental Science, Leiden, The Netherlands.

Hischer R. 2007. Life cycle inventories of packaging and graphical papers. Part IV: Packaging glass. Ecoinvent report No. 11. Swiss Centre for Life Cycle Inventories, Dubendorf, Switzerland.

Hischier R., Althaus H.J., Werner F. 2010. Developments in wood and packaging materials life cycle inventories in Ecoinvent. Int. J. Life Cycle Assess. 10:50-8.

Hospido A., Moreira M.T., Feijoo G. 2005. Environmental analysis of beer production. Int. J Agric. Resour. Gov. Ecol. 4:152-62.

Hunt R.G., Franklin W.E., Hunt R.G. 1996. LCA - How it came about. Int. J. Life Cycle Assess. 1:4-7.

IPCC (Intergovernmental Panel on Climate Change). 2013. Climate Change 2013: the physical science basis. Contribution of Working Group I to the Fifth Assessment Report of the Intergovernmental Panel on Climate Change. Cambridge University Press, Cambridge, UK and New York, NY, USA.

ISO (International Organisation for Standardisation). 2006a. IS0 14040:2006. Environmental management - Life cycle assessment Principles and framework. ISO, Geneve, Switzerland.

ISO (International Organisation for Standardisation). 2006b. ISO 14044:2006. Environmental management - Life cycle assessment Requirements and guidelines. ISO, Geneve, Switzerland.

Jenkin M.E., Hayman D.G. 1999. Photochemical ozone creation potentials for oxygenated volatile organic compounds: sensitivity to variations in kinetic and mechanistic parameters. Atmos. Environ. 33:1275-93.

Kanavouras A., Hernandez-Münoz P., Coutelieris F., Selke S. 2004.
Oxidation-derived flavour compounds as quality indicators for packaged olive oil. J. Am. Oil Chem Soc. 81:251-7.

Kiritsakis A.K., Dugan L.R. 1984. Effect of selected storage conditions and packaging materials on olive oil quality. J. Am. Oil Chem. Soc. 61:1868-70.

Koidis A., Boskou D. 2014. Virgin olive oil: losses of antioxidant polar phenolic compounds due to storage, packaging, and culinary uses. In: V. Preedy (Ed.), Processing and impact on active components in food. Elsevier Academic Press, London, UK, pp 267-274.

Krozer Y. 2008. Life cycle costing for innovations in product chains. J. Cleaner Prod. 16:310-21.

Limbo S., Peri C., Piergiovanni L. 2014. Extra-virgin olive oil packaging. In: C. Peri (Ed.), The extra-virgin olive oil handbook. WileyBlackwell, London, UK, pp. 179-199.

Luchs M.G., Naylor R.W., Irwin J.R., Raghunathan R. 2010. The sustainability liability: potential negative effects of ethicality on product preference. J. Marketing 74:18-31.

Madival S., Auras R., Singh S.P., Narayan R. 2009. Assessment of the environmental profile of PLA, PET and PS clamshell containers using LCA methodology. J. Cleaner Prod. 17:1183-94.

Masella P., Parenti A., Spugnoli P. 2012. Glass bottles of different sizes for the packaging of virgin olive oil: influence on shelf life. Riv. Ital. Sost. Grasse 89:161-5.

Mazzanti M., Zoboli V. 2008. Waste generation, waste disposal and policy effectiveness. Resour. Conserv. Recycl. 52:1221-34.

Pagani M., Vittuari M., Falasconi L. 2015. Does packaging matter? Energy consumption of pre-packed salads. Br. Food J. 117:1961-80.

Pattara C., Salomone R., Cichelli, A. 2016. Carbon footprint of extra virgin olive oil: A comparative and driver analysis of different production processes in Centre Italy. J. Clean. Prod. 127:533-47.

PlasticsEurope. 2013. Plastics - the facts 2013. An analysis of European latest plastics production, demand and waste. Available from: http://www.plasticseurope.org/Document/plastics-the-facts2013.aspx?Page $=$ DOCUMENT\&FolID $=2$

Prendergast G., Pitt L. 1996. Packaging, marketing, logistics and the environment: are there trade-offs?. Int. J. Phys. Distrib. Logist. Manage. 26:60-72.

Pristouri A.B.G. 2010. Effect of packaging material headspace, oxygen and light transmission, temperature and storage time on quality characteristics of extra virgin olive oil. Food Control 21:412-8.

Rokka J., Uusitalo L. 2008. Preference for green packaging in consumer product choices-do consumers care?. Int. J Consum. Stud. 32:516-25.

Roy P., Nei D., Orikasa T., Xu Q., Okadome H., Nakamura N., Shiina T. 2009. A review of life cycle assessment (LCA) on some food products. J. Food Engine. 90:1-10.

Russell R., Clifford S., William J.V. 2013. Steel production: processes, products, and residuals. Routledge, London, UK.

Thomson D. 1994. Electrolytic tin plating method. U.S. Patent No. US $5312539 \mathrm{~A}$

WMO (World Meterological Organization). 2006. Scientific assessment of ozone depletion. Global ozone research and monitoring project Report No. 50. WM0, Geneva, Switzerland.

World Resources. 1992. Guide to global environment. Available from: http://www.wri.org/publication/world-resources-1992-93. 